\title{
Editorial: Heavy Metal Carcinogens versus Human Health
}

\author{
Mishra S* \\ Department of Biotechnology, IFTM University, India
}

*Corresponding author: Sanjay Mishra, Department of Biotechnology, IFTM University, Delhi Road (NH 24), Moradabad 244102, Uttar Pradesh, India, Tel: +91-9837096059; Email: sanjaymishra@iftmuniversity.ac.in

\section{Editorial}

Volume 3 Issue 3

Received Date: May 14, 2018

Published Date: May 22, 2018

\section{Editorial}

Almost thirty chemical elements are persistently found in living organisms, taking part in vital biochemical and physiological functions, and recognized as essential elements for life. Those required in higher concentrations per day, form the main electrolytes and take part in the maintenance of the homeostasis. Those required in few micrograms to a few milligrams per day are Essential trace elements also participate in numerous biochemical vital processes necessary to maintain good health. Majority of the known metals and metalloids are very toxic to living organisms and even those considered as essential, can be toxic if present in excess. Metal ions present in the solid phase available under certain biological and physico-chemical conditions such as, exudation of special chelators, desorption, redox and $\mathrm{pH}$ changes, etc. The dietary contribution for toxic metal intake has been extensively studied [1].

Chemical elements present as free ions and those readily ionized are almost completely absorbed by the body. Transition metals readily form stable covalent complexes and usually interact as parts of macromolecules (proteins, enzymes, hormones, etc.) according to their chemical characteristics including oxidation state $[2,3]$. Health damage caused by toxic metals may be less (irritation) or acute (teratogenic, mutagenic and carcinogenic). Micronutrients can interact with toxic metals at several points in the body like absorption, transport, binding to target proteins, metabolism, sequestration, excretion of toxic metals and finally, in secondary symptoms of toxicity such as oxidative stress. Thus, a diet poor in micronutrients can have an important influence on the toxicity $[4,5]$. Moreover, contaminants possessing very long half-lives can be accumulated in the body and chronic effects are most often observed when critical concentrations are reached in target tissues. In brief, health effects of $\mathrm{Cd}$, $\mathrm{Pb}$, As and $\mathrm{Hg}$ are highlighted as follows:
Cadmium: Potential source of Cd toxicity is the use of commercial sludge to fertilize agricultural fields. Multiple fractures and severe pain in the legs and lower back affected mainly post-menopausal women with abnormal levels of glucose, calcium, and amino acids in their urine also the inhabitants of the community had for years been consuming rice contaminated by the effluent of a lead-zinc mine upstream from their rice paddies [6]. Cd exposure increased calcium excretion thus causes skeletal demineralization, which may lead to increases in bone fragility and risk of fractures [7]. Occupational human exposure has been correlated with lung cancer. $\mathrm{Cd}$ exposure, during human pregnancy, led to reduced birth weights and premature birth [8].

Lead: Lead enters the human body in many ways. It can be inhaled in dust from Lead paints, or waste gases from leaded gasoline. It is found in trace amounts in various foods, notably fish, which are heavily subjected to industrial pollution. $\mathrm{Pb}$ is a toxic metal and most people and animals receive the largest portion of their daily $\mathrm{Pb}$ intake via food. Cosmetics are also an important source of $\mathrm{Pb}$ contamination. The amount of $\mathrm{Pb}$ absorbed depends on age and the extent to which $\mathrm{Pb}$ particles are dissolved in the stomach. The proportion of $\mathrm{Pb}$ absorbed from the gastrointestinal tract is about $10 \%$ in adults, whereas levels of $40-50 \%$ have been reported for infants [9].

Arsenic: In the environment arsenic is usually found combined with other elements as inorganic and organic forms. Inorganic arsenic is more poisonous than organic one. Arsenic trioxide $\left(\mathrm{As}_{2} \mathrm{O}_{3}\right)$ is the most common inorganic arsenical in air, while arsenates $\left(\mathrm{AsO}_{4}\right)$ or arsenites $\left(\mathrm{AsO}_{2}\right)$ occur in water, soil, or food. Arsenic may be also necessary ultra-trace element for red algae, chickens, rats, goats, and pigs and its deficiency inhibited growth. Arsenic concentration is high in marine food. In fishes arsenic ranged between 5 to 100 


\section{International Journal of Biochemistry \& Physiology}

$\mu \mathrm{g} . \mathrm{g}^{-1}$, and reach to the range, of $100-250 \mu \mathrm{g}^{\mathrm{g}} \mathrm{g}^{-1}$ in species at the top of the food chain [10-12]. In humans arsenic toxicity have been occured due to ingestion of As-containing powders or solutions accidentally, for suicide, homicide, or consumption of contaminated food or drinking water.

Mercury: Hg and its compounds are highly toxic, wide dispersion through the atmosphere. It is biomagnified through the food chain. Mercury is organomercurial in the form of Methylmercury which have toxicological characteristics. Minamata disease name given after of methylmercury in seafood in Minamata and Niigata in Japan in the 1950-1960's, caused the death of thousands of people. Some studies suggest that even minor increases in methylmercury exposures can cause harmful effects on the cardiovascular system $[4,5]$. Renal toxicity of organic forms expressed by glomerulonephritis with proteinuria (glomerular and tubular) and nephritic syndrome $[4,5]$.

\section{Conclusions and Recommendations}

Conclusively, the heavy metals play important role in the production of ROS and NF-kB, also human genetic differences through polymorphisms in GST, metallothioneins and heavy metal methyltransferase genes induce carcinogenesis. Noticeably, heavy metals are epigenetic carcinogen, solely responsible for tumors presentation and progression [13]. Taken together the data presented herein and the ongoing research provide new insights and biochemical and molecular mechanisms involved in the development of pathological conditions in human.

\section{References}

1. Santos EE, Lauria DC, Porto da Silveira CL (2004) Assessment of daily intake of trace elements due to consumption of foodstuffs by adult inhabitants of Rio de Janeiro city. Sci Total Environ 327(1-3): 6979.

2. Schoof RA (2003a) Guide for Incorporating Bioavailability Adjustments into Human Health and Ecological Risk Assessments Part 1: Overview of Metals Bioavailability, Tri-Service Ecological Risk Assessment.

3. Schoof RA (2003b) Guide for Incorporating Bioavailability Adjustments into Human Health and Ecological Risk Assessments Part 2: Technical
Background Document for Assessing Metals Bioavailability, Tri-Service Ecological Risk Assessment.

4. Mudgal V, Madaan N, Mudgal A, Singh RB, Mishra S (2010) Effect of toxic metals on human health. The Open Nutraceuticals Journal 3: 94-99.

5. Mishra S, Dwivedi SP, Singh RB (2010) A review on epigenetic effect of heavy metal carcinogens on human health. The Open Nutraceuticals Journal 3: 188-193.

6. Oudeh M, Khan M, Scullion J (2002) Plant accumulation of potentially toxic elements in sewage sludge as affected by soil organic matter level and mycorrhizal fungi. Environ Pollut 116(2): 293-300.

7. Wu X, Jin $T$, Wang $Z$, Ye $T$, Kong $Q$ et al. (2001) Urinary calcium as a biomarker of renal dysfunction in a general population exposed to cadmium. J Occup Environ Med 43: 898-904.

8. Henson MC, Chedrese PJ (2004) Endocrine disruption by cadmium, a common environmental toxicant with paradoxical effects on reproduction. Exp Biol Med 229(5): 383-392.

9. Kaste JM, Friedland AJ, Sturup S (2003) Using stable and radioactive isotopes to trace atmospherically deposited $\mathrm{Pb}$ in montane forest soils. Environ Sci Technol 37: 3560-3567.

10. Michel $P$ (1993) Arsenic in marine medium; biochemistry and ecotoxicology, Pepères. Ocean n, $4^{\text {th }}(E d n)$, Ifremer, Paris.

11. Yoshida T, Yamauchi H, Fan Sun G (2004) Chronic health effects in people exposed to arsenic via the drinking water: dose-response relationships in review. Toxicol Appl Pharmacol 198(3): 243-252.

12. Walton FS, Harmon AW, Paul DS, Drobna Z, Patel YM, et al. (2004) Inhibition of insulin-dependent glucose uptake by trivalent arsenicals: possible mechanism of arsenic-induced diabetes. Toxicol Appl Pharmacol 198(3): 424-433.

13. Mishra S, Tiwari AKM, Mahdi AA (2019) Impact of heavy metal carcinogens on human health. In: Rai M (Ed.), Biomedical Applications of Metals. Springer International Publications $\mathrm{AG}$, part of Springer Nature, Chapter 13, pp: 277-295. 